\title{
Factors Affecting Net Benefit of Google Drive Adoption Decision: A Case Study of Thais' Living in Bangkok, Thailand
}

\author{
Submitted 11/09/19, 1st revision 01/10/19, $2^{\text {nd }}$ revision 29/10/19, accepted 09/11/19
}

\author{
Rawin Vongurai ${ }^{1}$
}

\begin{abstract}
:
Purpose: The research proceeded to investigate the factors affecting net benefit of google drive adoption decision among Thais living in Bangkok, Thailand.

Design/Methodology/Approach: The data were collected from 412 respondents through convenient sampling technique by online questionnaire. Information quality, system quality, service quality, user satisfaction, intention to use and net benefit, validity and reliability of each variables were examined by Confirmatory Factor Analysis (CFA) and Structural Equation Model (SEM).

Findings: The results showed that user satisfaction has the most direct effect on net benefit. Moreover, information quality, system quality and service quality were indirectly affected on net benefit of google drive. Therefore, google drive serve quality system that matches with customer satisfaction and expectation to improve job efficiency.

Practical Implications: Although previous studies have identified on the use of google drive in collaborative business operations. However, the factors behind the use of google drive cloud system and the decisions behind the adaptation would provide useful insights for better understanding of the mechanism.

Originality/Value: This research provides advanced recommendations to those who concern on the use of efficient google drive features not only to develop its features, but also to strengthen the smooth and flexible work patterns in organizations.
\end{abstract}

Keywords: Google drive, system quality, service quality, intention to use, user satisfaction, net benefit.

Article Type: Research Study.

\footnotetext{
${ }^{1}$ Lecturer of Graduate School of Business, Assumption University, Thailand, rawinvng@au.edu
} 


\section{Introduction}

The adoption of internet has led users to access almost everything through online platform. This also led businesses to identify a system in which their employees can work remotely with smooth collaboration. Over $50 \%$ of the workers mentioned in the Regus report that they work remotely for 2-3 days a week (Regus, 2017), whereas primarily they used to work from home almost 5 days a week (Buffer, 2018). With the advancement of cloud adoption, it has become a popular system suitable for businesses having advantages in both communication and services (Marston et al., 2011) Furthermore, flexibility and production improvement play as important role on cloud computing system (Xu, 2012).

In April 24, 2012, Google Drive has been launched which was developed by Google to store and synchronize data and share on cloud services. The drive offered functions as part of Office suit which can be edited by collaborative permits such as Documents or Words as Google Docs, Spreadsheets or Excel as Google Sheets, Presentation or PowerPoint as Google Slides that are coded to be saved in Google Drive system. The users have to sign-up for Gmail e-mail account to access the service system and one user will receive 15 Gigabytes of Free storage (modernsparkmedia.com).

In Thailand, the total population in 2019 were around 69.24 Million and there are 57 Million internet users (Hootsuite) whereas $85 \%$ of Thai workers reported that they are working outside at least 1 day per week (marketingoops.com). As per statistics from Global No.1 Business Data Platform (Statista.com), the current and planned usage of public cloud platform services as of 2019, Google Cloud or Google drive ranked 3rd place by $19 \%$ of currently running system which is behind from AWS from Amazon by $61 \%$ and Azure from Microsoft by $52 \%$. From previous studies, a lot of people and businesses use google drive through internet as a cloud service for collaboration, however the factors behind choosing Google drive on cloud system are important to study further. Therefore, this study will identify the factors affecting net benefit of google drive adoption decision of Thais living in Bangkok, Thailand.

The researcher identified the objectives as to analyze the information quality factors, effects of system quality and service quality on intention to use and user satisfaction towards google drive as well as to analyze the factors of intention to use and user satisfaction effect on net benefit of google drive adoption decision.

\section{Literature Review}

\subsection{Information Quality vs. Intention to Use}

Information quality (IQ) is a multi-dimensional concept that match with expectations, requirements and perception of the output quality that the receiver will get in terms of value such as Completeness, Consistency and accuracy of information 
(Ruzevicius \& Gedminaite, 2007; Knight \& Burn, 2005; DeLone \& McLean, 1992). Gefen et al. (2003), Igbaria et al. (1997) defined Intention to use (IN) as person's intention to perform a specific action. In 2014, Deng and Yang identified Information quality (IQ) as the factor affecting user's intention to use (IN) on google drive.

\subsection{Information Quality vs. User Satisfaction}

McKinney et al. (2002) identified Information quality (IQ) as one of the key constructs of User satisfaction (SAT). User satisfaction (SAT) is the factor that researchers take into consideration when studying technology and defined as the degree of satisfied users (SAT) with their decision to use and meet their expectations (Delone \& Mclean, 2003; Wang, 2008; Wang \& Liao, 2008; Roca et al., 2006). Information Quality (IQ) has a positive influential attitude and user satisfaction (SAT) towards google drive (Junglas et al., 2013; Xu, Benbasat \& Cenfetelli, 2013; Delone \& Mclean 1992).

\subsection{System Quality vs. Intention to Use}

System quality (SYQ) is the key to drive success of information system and shaping individuals' behaviors to use google drive. Moreover, it is defined as user's interaction to use google drive system (DeLone \& McLean, 2004; Nelson et al., 2005; Zhou et al., 2010). System quality (SYQ) influences and impacts users' behaviors while using or intention to use (IN) on Google drive (Fan \& Fang, 2006; Lee \& Lee, 2012).

\subsection{System Quality vs. User Satisfaction}

Customer's perception of outcome while using the system is one of the critical factors influencing User Satisfaction (SAT) of organizational performance (Cronin et al., 2000). Iacobucci et al. (1995) concluded that system quality (SYQ) reflects to customers' experiences and satisfaction with that service. Liang \& Zhang (2009) discovered that there is a positive relationship between system quality (SYQ) and user satisfaction (SAT).

\subsection{Service Quality vs. Intention to Use}

Service quality (SEQ) is a measurement factor of effectiveness and efficiency in evaluating performance of technology service delivered according to customer requirements (Jimenez et al., 2016; San-Martin et al., 2012; Lewis \& Booms (1983). There is relationship between service quality (SEQ) and intention to use (IN) google drive (Boulding et al.,1993; Cronin \& Taylor,1992)

\subsection{Service Quality vs. User Satisfaction}


Customer Satisfaction (SAT) is highly related to Service Quality (SEQ) as it is driven by perspectives and perceptions for service organizations (Cronin \& Taylor, 1994; Spreng \& MacKoy, 1996). Brodie et al. (2009) claimed that Service quality (SEQ) influences consumer perception of experience and satisfaction. In addition, Olsen (2002) showed that service quality (SEQ) predicts customer satisfaction (SAT).

\subsection{Intention to Use vs. Net Benefit}

Perceived net benefit (NB) has positive and negative impacts on user experiences towards Google Drive. User's net benefits (NB) mainly refers to cost savings, reduced time and increment of additional values (DeLone \& McLean 2003). Net Benefit (NB) has relationship towards intention to use (IN) google drive because it is a measure of users' utility from google drive. Agarwal and Karahanna (2000) have found the relationships between intention to use (IN) and conceptions involving net benefit (NB). Moveover, the researchers identified that relationships between perceived net benefit (NB) and intention to use (IN) google drive (Fishbein \& Ajzen, 1975; Lu et al.,2003).

\subsection{User satisfaction vs. Net Benefit}

DeLone \& McLean (2003) proposed feedback and benefits (NB) that makes user consistency to use the google drive system as well as declared that information quality (IQ), system quality (SYQ) and service quality (SEQ) have a significant effect on intention to use (IN) and user satisfaction (SAT). Many studies identified the relationship between User satisfaction (SAT) and Net Benefit (NB) (Staples et al., 2002; Wu \& Wang, 2006; Reynolds \& Beatty, 1999).

\section{Research Framework and Methodology}

\subsection{Research Framework}

The conceptual framework of this study (Figure 1) is to analyze the influential factors that are adopted from the case study named 'To cloud or not to cloud: how risks and threats are affecting cloud adoption decisions' conducted by Kajiyama et al. (2016). This research focused on information quality (IQ), system quality (SYQ), service quality (SEQ), intention to use (IN) and user satisfaction (SAT) that are affecting towards net benefit (NB) of Google drive.

The researcher developed the following eight hypotheses that are shown in Table 1 and are defined to align with the conceptual framework as followed: 


\section{Figure 1. Conceptual Framework}

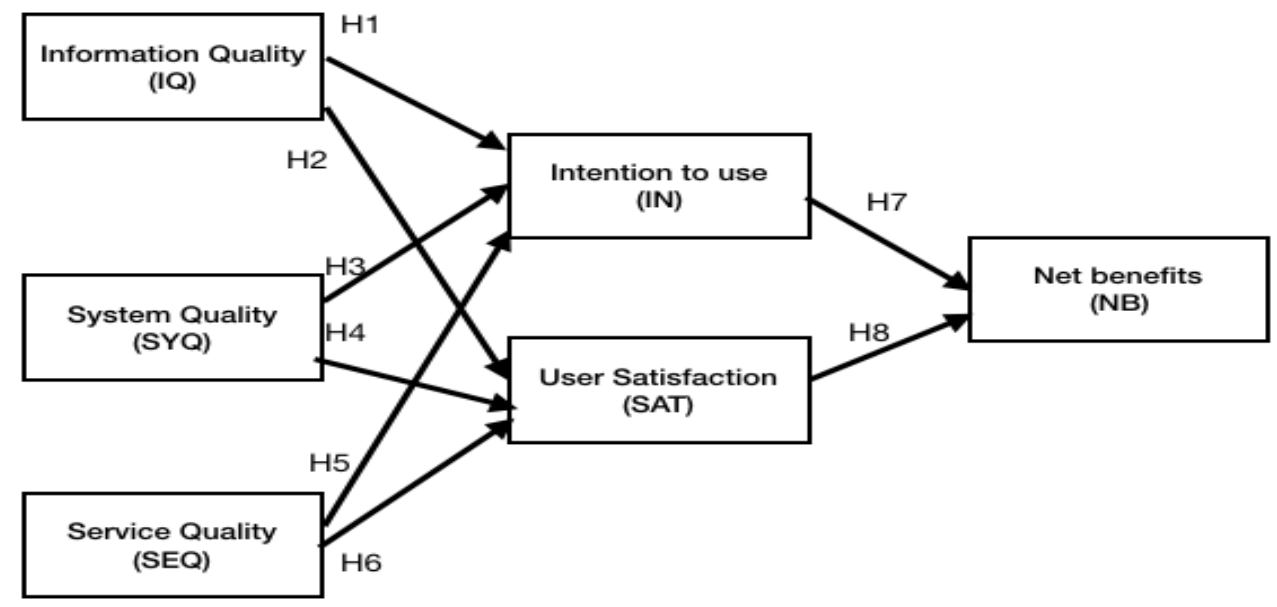

Table 1. Research Hypotheses

\begin{tabular}{|l|l|}
\hline $\mathbf{H}$ & Hypotheses \\
\hline $\mathrm{H}_{1}$ & $\begin{array}{l}\text { Information Quality (IQ) has significant direct effect on Intention to Use (IN) } \\
\text { Google drive. }\end{array}$ \\
\hline $\mathrm{H}_{2}$ & $\begin{array}{l}\text { Information Quality (IQ) has significant direct effect on User Satisfaction (SAT) } \\
\text { towards Google drive. }\end{array}$ \\
\hline $\mathrm{H}_{3}$ & $\begin{array}{l}\text { System Quality (SYQ) has significant direct effect on Intention to Use (IN) Google } \\
\text { drive. }\end{array}$ \\
\hline $\mathrm{H}_{4}$ & $\begin{array}{l}\text { System Quality (SYQ) has significant direct effect on User Satisfaction (SAT) } \\
\text { towards Google drive. }\end{array}$ \\
\hline $\mathrm{H}_{5}$ & $\begin{array}{l}\text { Service Quality (SEQ) has significant direct effect on Intention to Use (IN) Google } \\
\text { drive. }\end{array}$ \\
\hline $\mathrm{H}_{6}$ & $\begin{array}{l}\text { Service Quality (SEQ) has significant direct effect on User Satisfaction (SAT) } \\
\text { towards Google drive. }\end{array}$ \\
\hline $\mathrm{H}_{7}$ & $\begin{array}{l}\text { Intention to Use (IN) has significant direct effect on Net Benefit (NB) towards } \\
\text { Google drive. }\end{array}$ \\
\hline $\mathrm{H}_{8}$ & $\begin{array}{l}\text { User satisfaction (SAT) has significant direct effect on Net Benefit (NB) towards } \\
\text { Google drive. }\end{array}$ \\
\hline
\end{tabular}

\subsection{Methodology}

This research was conducted by performing the qualitative analysis of net benefit towards using Google drive among Bangkokians through a survey questionnaire method. The survey was conducted in a form of online questionnaires to collect required data. The survey consisted of three parts such as Screening questions, five points Likert scale and demographic factors. Firstly, the screening questions were defined to categorize respondents who are Thais working in Bangkok and had previous experience using Google drive. Secondly, the questions were designed to 
measure differences of six variables on five-point Likert scale. A five-point Likert scale was applied to analyze all hypotheses by differentiation ranging from strongly disagree (1) to strongly agree (5). Thirdly, demographic factors were defined to collect respondent's personal general information such as gender, age, marital status, income, occupation and different factors related to experiences from Google drive.

The researcher employed convenience sampling technique as a non-probability sampling method for data collection. The questionnaire was first distributed to 30 selected respondents to check the reliability of the instruments via online and Cronbach's alpha analysis is being used for the reliability testing. Afterwards, the complete and updated version of the questionnaire was distributed to collect 400 valid respondents of target group via online.

The sample size is calculated by Structural Equation Model (SEM). The collected data were analysis by using SPSS 24 and AMOS 18.0. Confirmatory Factor Analysis (CFA) is used for conducting the convergent validity and discriminant validity of the results. The measurement model fit was assessed to test the overall fitness with data and ensure the validity and reliability of the model. Lastly, the Structural Equation Model (SEM) was used to examine the influences among variables.

\section{Population and Sample Size}

The target respondents for this study focus on the respondents who are Thais working in Bangkok and had previous experiences using Google drive. The researcher focused on 18-24 years old target group who are interested on using internet. The sample size is calculated by SEM and prior to analyze the results, the sample size and number of factors should be considered. The number of variables and sample size are parallelly aligned. The appropriate sample size is considered to be minimum 300 respondents with six variables with low commonalities; for instance, below 0.45 (Hair et al., 2010). The total number of respondents who participated in the online survey were 487 from diverse demographic background. After screening the responses, the researcher identified 412 qualified responses to continue using in this research.

\section{Sampling Technique}

The researcher used convenience sampling technique as a non-probability sampling method to collect data from Thais working in Bangkok and had previous experiences using Google drive and considered the sample as the target population to distribute questionnaires using online channels in order to collect data. Convenience sampling technique, the questionnaires were distributed randomly through online channels to Thais working in Bangkok by the convenient accessibility and proximity of researcher's contact from each platform such as 'Facebook' and 'Line'. Meanwhile, sampling technique was developed by distributing the questionnaires to target 
respondents and afterwards letting them forward to their friends and colleagues who also have the required characteristics of one of the target respondents.

\subsection{Pilot Testing}

Cronbach's Alpha Coefficient is used to examine the reliability level of each variables in pilot testing that is included in the questionnaire. When the number of respondents reached to 30 responses, reliability test was executed through pilot testing. SPSS program is used to identify the reliability test and it was found that all the variables got value higher than 0.70 which was considered as acceptable and determined that the data has higher reliability (Tavakol \& Dennish, 2011). With reference to Table 2, the Cronbach's Alpha Coefficient falls under the range in between 0.704 to 0.904 which is greater than 0.7. So, this implies that the questionnaires that are developed for this study is achieved through the standard requirement for reliability test.

Table 2. Consistency of the Reliability Scale Test $(N=30)$

\begin{tabular}{|l|l|l|}
\hline Variables & Number of items & Cronbach's Alpha \\
\hline Information Quality (IQ) & 3 & 0.826 \\
\hline System Quality (SYQ) & 4 & 0.704 \\
\hline Service Quality (SEQ) & 4 & 0.708 \\
\hline Intention to Use (IN) & 4 & 0.904 \\
\hline User Satisfaction (SAT) & 4 & 0.861 \\
\hline Net Benefit (NB) & 3 & 0.735 \\
\hline
\end{tabular}

\section{Result and Discussion}

\subsection{Demographic Factors}

This section summarized the demographic profile summary of the 412 target respondents who are Thais working in Bangkok and had previous experiences from Google drive. The gender proportion of respondents who participated in this study was of male with $46.4 \%$ and female with $53.6 \%$. Majority of the respondents aged between $25-31$ years old with $76 \%$ and followed by the age in between 18-24 years old, 32-38 years old and 39 years old and above with the proportion of $13.6 \%, 6.6 \%$ and $3.9 \%$ respectively. Most of the respondents were single constituting $96.4 \%$ of the population whereas married at only $3.6 \%$.

The monthly income range of the respondents were proportionate with $39 \%$ had monthly income of in between 20,001 - 30,000 THB, 23.1\% had monthly income of in between 30,001 - 40,000 THB, 18.2\% had monthly income of in between 50,001 THB and above, 15.8\% had monthly income of in between 40,001 - 50,000 THB and $3.9 \%$ had monthly income of in between 10,000 - 20,000 THB. Majority of the respondents were employed in an organization with $101-1,000$ employees constituting $30.6 \%$ of the respondents followed by $26.7 \%$ with $11-100$ employees, 
$19.9 \%$ with $1,001-10,000$ employees, $13.6 \%$ with less than 10 employees, and $9.2 \%$ with 10,001 or more employees. Most of the respondents worked at the startups constituting $34.5 \%$ of the respondents, public firms at $30.1 \%$, private firms at $29.1 \%$ and government firms at only $6.3 \%$. Moreover, aside to the type of industry, $26.9 \%$ was service based, $25.7 \%$ was from retail \& wholesale, $14.6 \%$ was from finance \& insurances, $10.2 \%$ from real estate, $9.5 \%$ from internet \& information technology, $6.3 \%$ from manufacturing, $3.9 \%$ from transportation and lastly $2.9 \%$ from other types of firms operating in Bangkok, Thailand.

Table 3. Demographic Profile

\begin{tabular}{|l|l|l|l|}
\hline Demographical and Behavior Data (N= 412) & Frequency & Percentage \\
\hline Gender & Male & 191 & $46.4 \%$ \\
& Female & 221 & $53.6 \%$ \\
\hline Age & $18-24$ years old & 56 & $13.5 \%$ \\
& 25-31 years old & 313 & $76.0 \%$ \\
& $32-38$ years old & 27 & $6.6 \%$ \\
& 39 years old and above & 16 & $3.90 \%$ \\
\hline Marital Status & Single & 397 & $96.4 \%$ \\
& Married & 15 & $3.6 \%$ \\
\hline Monthly Income & $10,000-20,000$ THB & 16 & $3.9 \%$ \\
& $20,001-30,000$ THB & 161 & $39 \%$ \\
& $30,001-40,000$ THB & 95 & $23.1 \%$ \\
& $40,001-50,000$ THB & 65 & $15.8 \%$ \\
& 50,001 THB and Above & 75 & $18.2 \%$ \\
\hline Employees & Less than 10 & 56 & $13.6 \%$ \\
& $11-100$ & 110 & $26.7 \%$ \\
& $101-1,000$ & 126 & $30.6 \%$ \\
& $1,001-10,000$ & 82 & $19.9 \%$ \\
& 10,001 or more & 38 & $9.2 \%$ \\
\hline Type of organization & Start-up & 142 & $34.5 \%$ \\
& Government & 26 & $6.3 \%$ \\
& Private Sector & 120 & $29.1 \%$ \\
& Public Sector & 124 & $30.1 \%$ \\
\hline Type of Industry & Finance, insurance & 60 & $14.6 \%$ \\
& Real estate & 42 & $10.2 \%$ \\
& Internet, information technology & 39 & $9.5 \%$ \\
& Manufacturing & 26 & $6.3 \%$ \\
& Retail, wholesale & 106 & $25.7 \%$ \\
& Service & 111 & $26.9 \%$ \\
& Transportation & 16 & $3.9 \%$ \\
& Others & 12 & $2.9 \%$ \\
\hline
\end{tabular}

\subsection{Confirmatory Factor Analysis (CFA)}

CFA has provided a validation test of how the data fits in with the conceptual model in this research. In details, CFA can examine the result of factor loading which must be higher than 0.30 (Kline, 1994). Moreover, the composite reliability (CR) should 
be above than 0.7 and the Average Variance Extracted (AVE) that used for convergent validity should be above than 0.5 (Hair et al., 2010). The result illustrated that all the criteria is greater than the required number as described in Table 4.

The discriminant validity is used to evaluate between each variable by calculating the square root of the AVE. An individual's variables normally should be greater than the covariant relation between variables in the model. This can be confirmed that Table 5 indicated the correlation coefficients between two variables that are smaller than the AVE square roots of the measurement variables of the constructs.

Table 4. Confirmatory Factor Analysis Result, Composite Reliability (CR) and Average Variance Extracted (AVE)

\begin{tabular}{|l|l|l|l|l|l|}
\hline Variables & $\begin{array}{l}\text { Factor } \\
\text { Loading }\end{array}$ & S.E. & T-value & CR & AVE \\
\hline Information Quality (IQ) & & & & \\
IQ1 & .897 & & & 0.863 & 0.684 \\
IQ2 & .922 & .065 & $19.763^{* * *}$ & & \\
IQ3 & .630 & .058 & $14.079^{* * *}$ & & \\
\hline System Quality (SYQ) & & & & 0.817 & 0.529 \\
SYQ1 & .799 & & & & \\
SYQ2 & .713 & .069 & $10.263^{* * *}$ & & \\
SYQ3 & .761 & .080 & $11.606^{* * *}$ & & \\
SYQ4 & .624 & .065 & $7.328^{* * *}$ & & \\
\hline Service Quality (SEQ) & & & & 0.805 & \\
SEQ1 & .780 & & & & \\
SEQ2 & .693 & .071 & $10.715^{* * *}$ & & \\
SEQ3 & .802 & .086 & $12.695^{* * *}$ & & \\
SEQ4 & .565 & .104 & $9.176^{* * *}$ & & \\
\hline Intention to Use (IN) & & & & 0.888 & \\
IN1 & .793 & & & & \\
IN2 & .545 & .033 & $15.271^{* * *}$ & & \\
IN3 & .951 & .060 & $25.390^{* * *}$ & & \\
IN4 & .929 & .061 & $23.901^{* * *}$ & & \\
\hline User Satisfaction (SAT) & & & & 0.673 \\
SAT1 & .726 & & & \\
SAT2 & .907 & .068 & $18.867^{* * *}$ & & \\
SAT3 & .432 & .065 & $8.687^{* * *}$ & & \\
SAT4 & .982 & .083 & $19.019^{* * *}$ & & \\
\hline Net Benefit (NB) & .621 & .095 & $10.373^{* * *}$ & & \\
NB1 & .897 & .171 & $9.586^{* * *}$ & & \\
NB2 & & & 0.767 & \\
NB3 & & & \\
\hline Note: & & & \\
\hline
\end{tabular}

Note: $C R=$ Composite Reliability, $A V E=$ Average Variance Extracted $* * *=$ Significant at the 0.05 significant levels $(p<0.05)$ 
Factors Affecting Net Benefit of Google Drive Adoption Decision: A Case Study of Thais' Living in Bangkok, Thailand

158

Table 5. Discriminant validity

\begin{tabular}{|l|l|l|l|l|l|l|}
\hline & NB & IQ & SYQ & SEQ & IN & SAT \\
\hline NB & $\mathbf{. 7 2 9}$ & & & & & \\
\hline IQ & .426 &. $\mathbf{7 9 1}$ & & & & \\
\hline SYQ & .473 & .313 &. $\mathbf{8 2 1}$ & & & \\
\hline SEQ & .330 & .319 & .500 &. $\mathbf{7 1 6}$ & & \\
\hline IN & .637 & .347 & .353 & .332 &. $\mathbf{7 2 7}$ & \\
\hline SAT & .564 & .342 & .366 & .365 & .674 & $\mathbf{. 8 2 7}$ \\
\hline
\end{tabular}

Note: The diagonally listed values are the AVE square roots of the variables

\subsection{Structural Equation Model (SEM)}

Structural Equation Model (SEM) is used to test the measurement and the structural regression of model. After running SEMs and revising the model, the overall model fit index has passed all the criteria as measurable criteria refer to Table 6.

Table 6. Goodness of Fit

\begin{tabular}{|l|l|l|}
\hline Index & Criteria & Result of this study \\
\hline CMIN/DF & $<3.00$ & 2.851 \\
\hline GFI & $>0.90$ & 0.915 \\
\hline AGFI & $>0.90$ & 0.902 \\
\hline NFI & $>0.90$ & 0.906 \\
\hline CFI & $>0.90$ & 0.951 \\
\hline TLI & $>0.90$ & 0.932 \\
\hline RMSEA & $<0.08$ & 0.071 \\
\hline RMR & $<0.05$ & 0.048 \\
\hline
\end{tabular}

Note: $C M I N / D F=$ The ratio of the chi-square value to degree of freedom, GFI = goodnessof-fit index, AGFI = adjusted goodness-of-fit index, NFI = normalized fit index, TLI = Tucker-Lewis index, CFI = comparative fit index, RMSEA = root mean square error of approximation, and $R M R=$ root mean square residual.

\section{Research Hypotheses Testing}

The results of hypothesized test are represented in Table 7, the result applied that all hypotheses are supported. The result from Table 7 can be summarized as below:

$\mathrm{H}_{1}$ : The standardized path coefficient between information quality and intention to use was $0.275\left(\mathrm{t}\right.$-value $\left.=6.182^{* * *}\right)$. Information quality has significant effect towards intention to use. Thus, $\mathrm{H}_{1}$ was supported. 
Table 7. Hypothesis Result of the Structural Model

\begin{tabular}{|l|l|l|l|}
\hline Hypotheses & $\begin{array}{l}\text { Standardized path } \\
\text { coefficients ( } \beta)\end{array}$ & T-value & $\begin{array}{l}\text { Test } \\
\text { result }\end{array}$ \\
\hline $\begin{array}{l}\mathrm{H}_{1}: \text { Information Quality => Intention to } \\
\text { Use }\end{array}$ & .275 & $6.182^{* * *}$ & Supported \\
\hline $\begin{array}{l}\mathrm{H}_{2}: \text { Information Quality => User } \\
\text { satisfaction }\end{array}$ & .317 & $5.305^{* * *}$ & Supported \\
\hline $\mathrm{H}_{3}:$ System Quality => Intention to Use & .480 & $6.566^{* * *}$ & Supported \\
\hline $\mathrm{H}_{4}:$ System Quality => User satisfaction & .365 & $4.295^{* * *}$ & Supported \\
\hline $\mathrm{H}_{5}:$ Service Quality => Intention to Use & .181 & $2.313^{* * *}$ & Supported \\
\hline $\mathrm{H}_{6}:$ Service Quality => User Satisfaction & .175 & $1.997^{* * *}$ & Supported \\
\hline $\mathrm{H}_{7}:$ Intention to Use => Net Benefits & .252 & $4.798^{* * *}$ & Supported \\
\hline $\mathrm{H}_{8}:$ User Satisfaction => Net Benefits & .320 & $24.397^{* * *}$ & Supported \\
\hline
\end{tabular}

Note: $* * * p<0.05$.

$\mathrm{H}_{2}$ : The standardized path coefficient between information quality and user satisfaction was $0.317\left(\mathrm{t}\right.$-value $\left.=5.305^{* * *}\right)$. Information quality has significant effect towards user satisfaction. Thus, $\mathrm{H}_{1}$ was supported.

$\mathrm{H}_{3}$ : The standardized path coefficient between system quality and intention to use was $0.480(\mathrm{t}$-value $=6.566)$. System quality has significant effect towards intention to use. Thus, $\mathrm{H}_{3}$ was supported.

$\mathrm{H}_{4}$ : The standardized path coefficient between system quality and user satisfaction was 0.365 (t-value $=4.295)$. System quality has significant effect towards user satisfaction. Thus, $\mathrm{H}_{4}$ was supported.

$\mathrm{H}_{5}$ : The standardized path coefficient between system quality and intention to use was 0.181 (t-value $=2.313$ ). System quality has significant effect on intention to use. Thus, $\mathrm{H}_{5}$ was supported.

$\mathrm{H}_{6}$ : The standardized path coefficient between system quality and user satisfaction was 0.175 (t-value $=1.997)$. System quality has significant effect on user satisfaction. Thus, $\mathrm{H}_{6}$ was supported.

$\mathrm{H}_{7}$ : The standardized path coefficient between intention to use and net benefits was 0.252 (t-value $=4.798$ ). Intention to use has significant effect on net benefits. Thus, $\mathrm{H}_{7}$ was supported.

$\mathrm{H}_{8}$ : The standardized path coefficient between user satisfaction and net benefits was 0.320 (t-value $=24.397$ ). Intention to use has significant effect on net benefits. Thus, $\mathrm{H}_{8}$ was supported. 


\subsection{Direct, Indirect, and Total Effects of Relationships}

The relationships between variables are determined by sum total of direct effect and indirect effect. Direct effect means that an independent directly influence or effect on a dependent variable without the help of mediating variables. On the other hand, indirect effect means that independent variables indirectly influence or effect on a dependent variable through the help of mediating variables and the total effect is the sum of direct and indirect effects (Asher, 1983).

The researcher used AMOS program to analyze the direct, indirect and total effect as shown in Table 8. Figure 2 also showed the structural equation model of this research.

Table 8. Direct, Indirect, and Total Effects of Relationships

\begin{tabular}{|c|c|c|c|c|c|c|}
\hline \multicolumn{7}{|c|}{ Independent Variables } \\
\hline $\begin{array}{l}\text { Dependent } \\
\text { Variables }\end{array}$ & Effect & $\begin{array}{l}\text { Information } \\
\text { Quality }\end{array}$ & $\begin{array}{l}\text { System } \\
\text { Quality }\end{array}$ & $\begin{array}{l}\text { Service } \\
\text { Quality }\end{array}$ & $\begin{array}{l}\text { Intention } \\
\text { to Use }\end{array}$ & $\begin{array}{l}\text { User } \\
\text { Satisfaction }\end{array}$ \\
\hline \multirow[t]{4}{*}{$\begin{array}{l}\text { Intention to } \\
\text { Use }\end{array}$} & $\mathrm{DE}$ & $.275^{* * *}$ & $.480^{* * *}$ & $.181^{\text {*** }}$ & - & - \\
\hline & IE & - & - & - & - & - \\
\hline & $\mathrm{TE}$ & $.275^{* * *}$ & $.480^{* * *}$ & $.181^{* * *}$ & & \\
\hline & $\mathrm{R}^{2}$ & \multicolumn{5}{|l|}{.106} \\
\hline \multirow[t]{4}{*}{$\begin{array}{l}\text { User } \\
\text { Satisfaction }\end{array}$} & $\mathrm{DE}$ & $.317^{* * *}$ & $.365^{* * *}$ & $.175^{* * *}$ & - & - \\
\hline & IE & - & - & - & - & - \\
\hline & $\mathrm{TE}$ & $317^{* * *}$ & $.365^{* * *}$ & $.175^{* * *}$ & & \\
\hline & $\mathrm{R}^{2}$ & \multicolumn{5}{|l|}{.410} \\
\hline \multirow[t]{4}{*}{ Net Benefit } & $\mathrm{DE}$ & - & - & - & $.252^{* * *}$ & $.320^{* * *}$ \\
\hline & IE & $487^{* * *}$ & $.361^{* * *}$ & $277^{* * *}$ & - & - \\
\hline & $\mathrm{TE}$ & $.487^{* * *}$ & $.361^{* * *}$ & $277^{* * *}$ & $.252^{* * *}$ & $.320^{* * *}$ \\
\hline & $\mathrm{R}^{2}$ & \multicolumn{5}{|l|}{.851} \\
\hline
\end{tabular}

Note: $D E=$ Direct Effect, $I E=$ Indirect Effect, $T E=$ Total Effect $(D E+I E), * * *=p<0.05$.

The result from Table 8 can be explained that:

Intention to Use: The significant direct effect of system quality on intention to use was 0.480 . The significant direct effect of information quality on intention to use was 0.275 . The significant direct effect of service quality on intention to use was 0.181 . Therefore, the researcher could not find indirect effect and as a result, the direct effects were equal to the total effects. In terms of total effect, system quality is the most important variable that significantly effect on intention to use. 
Figure 2. The Results of Structural Model

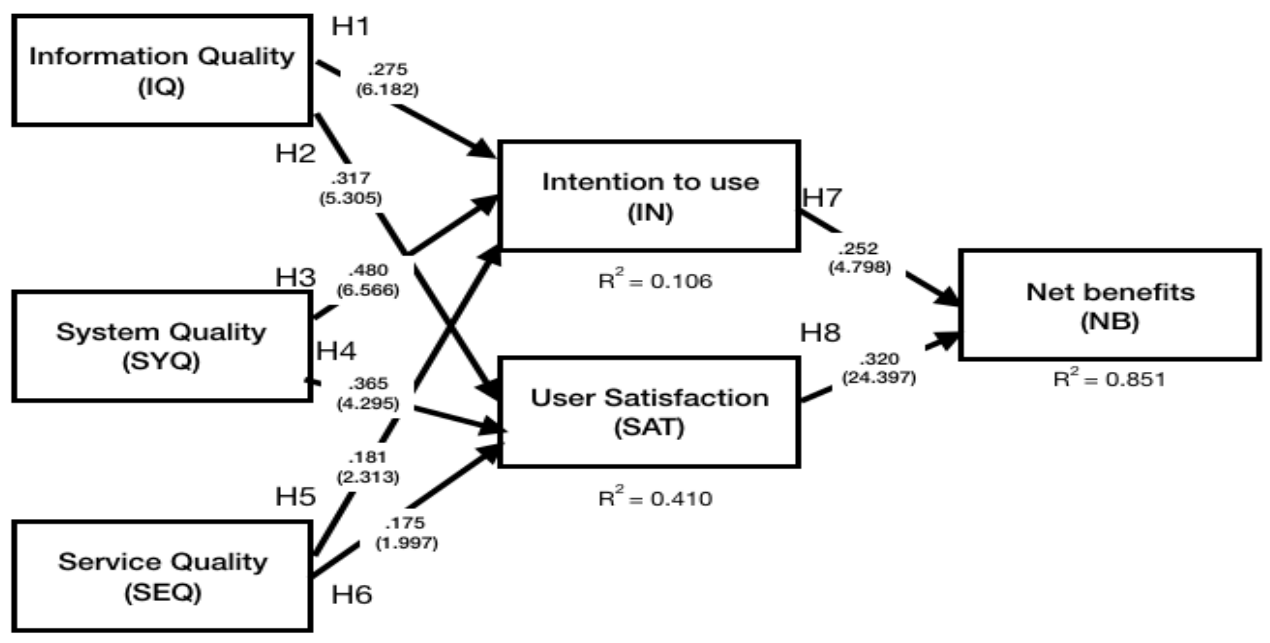

User Satisfaction: The significant direct effect of system quality on user satisfaction was 0.365 . The significant direct effect of information quality on user satisfaction was 0.317 . The significant direct effect of service quality on user satisfaction was 0.175 . There was no indirect effect found, so the direct effects were equal to the total effects. In terms of total effect, system quality is the most important variable that significantly effect on user satisfaction.

Net Benefit: The significant direct effect of user satisfaction on net benefit was 0.320 . The significant direct effect of intention to use on user net benefit was 0 . 252. Whereas few indirect effects are shown in Table 8 . The significant indirect effect of information quality on net benefit was 0.487 . The significant indirect effect of system quality on net benefit was 0.361 and the insignificant indirect effect of service quality on net benefit was 0.277 .

To summarize, user satisfaction has the most significantly effect on net benefit of google drive (.320) followed by the effect of system quality on user satisfaction on google drive (0.365), information quality (0.317) and service quality $(0.175)$.

\section{Conclusion, Recommendation and Limitation}

\subsection{Conclusion}

The objectives of this research are to investigate factors affecting net benefit of google drive adoption decision of Thais living in Bangkok, Thailand. The conceptual framework was adopted from case study named 'To cloud or not to cloud: how risks and threats are affecting cloud adoption decisions' that was composed of information quality, system quality, service quality, intention to use, user satisfaction and net 
benefit. The questionnaire was distributed to respondents residing in Bangkok Thailand and had been living or working in Bangkok and experienced Google drive previously. The results were analyzed by Confirmatory Factor Analysis (CFA) verifying the validity and reliability of the model. Furthermore, the effects among variables were examined by Structural Equation Model (SEM).

User satisfaction had the most direct effect on net benefit of google drive because the various programs of google drive such as office suit programs of google doc, google sheet and google slide as well as having many third party apps that work with the drive, and services itself which meet their expectation to improve their speed and efficiency at work. Further analysis has shown that information quality, system quality and service quality also directly affect to user satisfaction in which system quality has greater effect on user satisfaction than others. These also indicated that information quality, system quality and service quality were indirectly affected to net benefit. Google drive is not required for an expert or trainer to train, but it is easy to use which qualifies only basic computer skills and provides prompt responses to users, that is why Thais prefer Google drive for their daily business operations.

\subsection{Recommendations}

The results of this research represented that net benefit of google drive depends on information quality, system quality, service quality, intention to use and user satisfaction in which satisfaction and system quality have strong effect towards net benefit. This research provides recommendations to those who concern for developing google drive features to acquire more users in the future.

Firstly, a complete range of program not only office suit that support general needs but also google drive which could provide other niche programs such as song or music composed apps to support music producers to reach all range of occupation. Secondly, more visually attractive, the layout itself is general which it could be better for more attractive and friendly on each person such as customized or additional functions on color insert to their own background. Thus, reliability on google drive, most of the customers rely on google drive but it should communicate to others who did not know yet that the quality of google drive are second to none. Not only to build reliability of existing customers but also to gain more new customers and businesses. All of these features will influence user satisfaction and system quality, in which google drive will be more interesting and fulfilling their net benefit.

\section{Limitation and Further Study}

There are certain limitations of this research which is on the factors affecting net benefit of google drive adoption decision of Thais living in Bangkok, Thailand that should be applied in further research. This research data was collected only from Thais living in Bangkok. Therefore, further studies should be applied diversely on 
areas to learn more on different contexts. Moreover, its focus only on google drive, further studies should be considered on other cloud services.

Furthermore, a small number of factors which might not cover all the measurable factors affecting net benefit of google drive adoption decision. For further studies, in gaining more insights and understanding, may add on certain factors such as trust, ease of use or knowledge in order to add more value of the studies.

\section{References:}

Agarwal, R. and Karahanna, E. 2000. Time flies when you're having fun: cognitive absorption and beliefs about information technology usage. MIS Quarterly, 24, 4, 665-694.

Boulding, W., Kalra, A., Richard, S. and Zeithaml, V.A. 1993. A dynamic process model of service quality: from expectations to behavioral intentions. Journal of Marketing Research, Vol. 30, No. 1, pp. 7-27.

Brodie, R.J., Whittome, J.R. and Brush, G.J. 2009. Investigating the service brand: a customer value perspective. Journal of Business Research, 62, No. 3, pp. 345-355.

Cochan,W.G. 1977. Sampling technique, Third edition. New York, Johm Wiley \& Sons. Cronbach, L. 1951. Coefficient alpha and the internal structure of tests. Psychomerika, 16, 297-334.

Cronin, J.J. and Taylor, S.A. 1992. SERVPERF versus SERVQUAL: reconciling performance-based and perceptions-minus-expectations measurement of service quality. Journal of marketing, Vol. 58, No. 1, 125-131.

Cronin, J.J., Brady, M.K. and Hult, G.T.M. 2000. Assessing the effects of quality, value, and customer satisfaction on consumer behavioral intentions in service environments. Journal of Retailing, Vol. 76, No. 2, 193-218.

DeLone, W.H. and McLean, E.R. 1992. Information systems success: the quest for the dependent variable. Information Systems Research, Vol. 3, No. 1, 60-95.

Delone, W.H. and Mclean, E.R. 2003. The DeLone and McLean model of information systems success: a ten-year update. Journal of Management Information System, Vol. 19, No. 4, pp. 9-31.

DeLone, W.H. and McLean, E.R. 2004. Measuring e-commerce success: applying the DeLone \& McLean information systems success model. International Journal of Electronic Commerce, Vol. 9, pp. 31-47.

Deng, L. and Yang, W. 2014. On factors affecting college students' continued mobile library usage behavior and its measurements-based on expanded expectation-confirmation model of IS continuance. Library Tribune, Vol. 2014, No. 2, pp. 63-68.

Fan, J.C. and Fang, K. 2006. ERP implementation and information systems success: a test of DeLone and McLean's model. Technology Management for the Global Future, 2006. PICMET. 2006, Vol. 3.

Fishbein, M. and Ajzen, I. 1975. Belief, Attitude, Intention, Behavior: An Introduction to Theory and Research. Addison Wesley, Reading, MA.

Gefen, D., Karahanna, E. and Straub, D.W. 2003. Trust and TAM in online shopping: an integrated model. MIS Quarterly, Vol. 27, No. 1, 51-90.

Hair, J.F., Black, W.C., Babin, B.J. \& Anderson, R.E. 2010. Multivariate Data Analysis. Pearson Education.

Iacobucci, D., Ostrom, A. and Grayson, K. 1995. Distinguishing service quality and 
customer satisfaction: the voice of the consumer. Journal of Consumer Psychology, Vol. 4, No. 3, 277-303.

Igbaria, M., Zinatelli, N., Cragg, P. and Cavaye, A.L.M. 1997. Personal computing acceptance factors in small firms: a structural equation model. MIS Quarterly, Vol. 21, No. 3, 279-305.

Jimenez, N., San-Martin, S. and Azuela, J.I. 2016. Trust and satisfaction: the keys to client loyaltyin mobile commerce. Academia Revista Latinoamericana De Administracion, Vol. 29, No. 4, 486-510.

Junglas, I., Goel, L., Abraham, C. and Ives, B. 2013. The social component of information systems-how sociability contributes to technology acceptance. Journal of the Association for Information Systems, Vol. 14, No. 10, 585-616.

Kajiyama, T., Jennex, M. \& Addo, T. 2017. To cloud or not to cloud: how risks and threats are affecting cloud. Information \& Computer Security, 634-659.

Kline, P. 1994 An Easy Guide to Factor Analysis. Routledge, New York.

Knight, S. and Burn, J. 2005. Developing a framework for assessing information quality on the World Wide Web. Informing Science, Vol. 8, 159-172

Lee, S.M. and Lee, S.H. 2012. Success factors of open-source enterprise information systems development. Industrial Management \& Data Systems, Vol. 112, 1065-1084.

Lewis, R.C. and Booms, B.H. 1983. The Marketing Aspects of Service Quality. In Berry, L.L., Shostack, G.S. and Upah, G. (Eds), Emerging Perspectives on Service Marketing. American Marketing Association, Chicago, IL, 99-107.

Liang, X. and Zhang, S. 2009. Investigation of customer satisfaction in student food service. International Journal of Quality and Service Sciences, Vol. 1, No. 1, 113-124.

Lu, J., Yu, C.S., Liu, C. and Yao, J. 2003. Technology acceptance model for wireless internet. Journal of Internet Research, Vol. 13, No. 2, 206-222.

Marketingoops, 2019. Digital Trend 2019. Retrieved from https://www.marketingoops.com/reports/global-and-thailand-digital-trend-2019/

Marston, S., Li, Z., Bandyopadhyay, S., Zhang, J. and Ghalsasi, A. 2011. Cloud computing the business perspective. Decision Support Systems, Vol. 51. No. 1, 176-189.

McKinney, V., Yoon, K. and Zahedi, F.M. 2002. The measurement of web-customer satisfaction: an expectation and disconfirmation approach. Information System Research, Vol. 13, No. 3, 296-315.

Modernsparkmedia. 2012. Retrieved from Google Drive. http://modernsparkmedia.com/728/google-drive/

Nelson, R.R., Todd, P.A. and Wixom, B.H. 2005. Antecedents of information and system quality: an empirical examination within the context of data warehousing. Journal of Management Information Systems, Vol. 21, 199-235.

Olsen, S.O. 2002. Relationship between quality, satisfaction and repurchase loyalty. Journal of the Academy of Marketing Science, Vol. 30, No. 3, 240-249.

Regus, 2017, Regus plc Annual Report and Accounts 2017. Retrieved from http://assets.regus.com/investors/annual-reports/2017/2018.04.27-regus-plcconsolidated-report-and-accounts2017.pdf\#_ga=2.202312209.1024346318.1573462157-2053324376.1573462157

Reynolds, K.E. and Beatty, S.E. 1999. Customer benefits and company consequences of a retail-customer relationship. Journal of Retailing, Vol. 75, No. 1, 11-32.

Roca, J.C., Chiu, C.M. and Martínez, F.J. 2006. Understanding e-learning continuance intention: an extension of the technology acceptance model. International Journal of Human-Computer Studies, Vol. 64, No. 8, 683-696.

Ruzevicius, J. and Gedminaite, A. 2007. Business information quality and its assessment. 
Engineering Economics, Vol. 52, 18-25.

San-Martin, S., Lopez-Catalán, B. and Ramon-Jeronimo, M.A. 2012. Factors determining firms'perceived performance of mobile commerce. Industrial Management and Data Systems, Vol. 112, No. 6, 946-963.

Staples, D.S., Wong, I. and Seddon, P.B. 2002. Having expectations of information systems benefits that match received benefits: does it really matter? Information and Management, Vol. 40, 115-131.

Statista. 2019. Retrieved from Current and planned usage of public cloud platform services running applications worldwide as of 2019. https://www.statista.com/statistics/511467/worldwide-survey-public-coud-servicesrunning-application/

Tavakol, M. \& Dennick, R. 2011. Making sense of Cronbach's alpha. Making Sense of Cronbach's Alpha, 1-3. Retrieved from https://www.ijme.net/archive/2/cronbachsalpha.pdf

Wang, Y.S. and Liao, Y.W. 2008. Assessing e-Government systems success: a validation of the DeLone and McLean model of information systems success. Government Information Quarterly, Vol. 25, No. 4, 717-733.

Wang, Y.S. 2008. Assessing e-commerce systems success: a respecification and validation of the DeLone and McLean model of IS success. Information Systems Journal, 18, 529-557.

Wu, J.H. and Wang, Y.M. 2006. Measuring KMS success: a respecification of the DeLone and McLean's model. Information and Management, 43, 728-739.

Xu, J., Benbasat, I. and Cenfetelli, R.T. 2013. Integrating service quality with system and information quality: an empirical test in the e-service context. MIS Quarterly, 37, 3, 777-794.

$\mathrm{Xu}, \mathrm{X}$. 2012. From cloud computing to cloud manufacturing. Robotics and ComputerIntegrated Manufacturing, Vol. 28, No. 1, 75-86.

Zhou, T., Li, H. and Liu, Y. 2010. The effect of flow experience on mobile SNS users' loyalty. Industrial Management \& Data Systems, Vol. 110, 930-946. 